\title{
Caesarean delivery mode and its impact on children's growth and cognitive development
}

Received $25^{\text {th }}$ August 2020, Accepted $15^{\text {th }}$ September 2020

Link to DOI:

10.25220/WNJ.V04.S2.0004

Journal Website:

www.worldnutrijournal.org
Rini Sekartini ${ }^{1}$, Levina Chandra Khoe ${ }^{2}$

1. Department of Pediatric, Medical Faculty, Universitas Indonesia-Cipto Mangunkusumo National Hospital, Indonesia

2. Department of Community Medicine, Medical Faculty, Universitas Indonesia

\begin{abstract}
There is an increasing concern on the potential risk of Caesarean birth on child health outcomes. This study aims to present the current available evidences on the effect of Caesarean section on child's growth and development. Literature searching were done on several online databases to identify articles which discussed the effect of Caesarean birth on child's body weight, length, nutritional status, cognitive development, memory, learning ability, and intelligence quotient. Several studies showed positive association between Caesarean and risk of overweight and obesity in childhood, adolescence, and adulthood. While, there has not been sufficient evidences to confirm the association between C-section and child's cognitive outcomes.
\end{abstract}

Keywords: Caesarean section, children, cognitive, growth and development

\section{Introduction}

Concerns have been raised due to increasing number of Caesarean deliveries towards the health of mother and baby. There are evidences that linked Caesarean section (C-section) with child health outcomes., Data from 150 countries from year 1990 to 2014 recorded the rate of global C-section was $18.6 \%$. In Indonesia, the Basic Health Research (2018) found about $17.6 \%$ of all births were delivered by Csection. ${ }^{3}$ This number exceeds the standards of the World Health Organization, as increase in C-section rate above $10 \%$ had no association with the reduction of maternal, neonatal, and infant mortality rates. ${ }^{4,5}$

\section{Corresponding author:}

dr. Levina Chandra Khoe, MPH

Department of Community Medicine

Medical Faculty, Universitas Indonesia

Email: levina.chandra01@ui.ac.id
Initially, C-section was introduced to save mothers and infant's lives. This surgical delivery is important and necessary if used according to medical indications. Unfortunately, many C-sections were performed no longer on the basis of medical indications. Maternal request contributed the most to the rising trend of C-section. ${ }^{6}$ The most common reason was fear of birth. Hence, medical indications for maternal and infants were not the top priority reasons. Mothers should be informed with all possible risks and benefits of $\mathrm{C}$-section before making decision on birth mode.

The difference birth mechanism between vaginal delivery and C-section could possibly affect child's health. C-section is considered an unnatural birth mode, in which it lack the birth canal compression and involves surgical procedures that might reduce the early mother-child interaction. ${ }^{7}$ In recent years, researchers have done many investigations to understand the possible adverse effect of C-section on child growth and development. 
This article is part of Series on Caesarean Section. We aimed to describe the potential health risks of Csection on child growth and cognitive development. In regards to child behavior, it will be discussed in a separate article.

\section{Methods}

We identified articles through various sources, such as online database (PubMed/Cochrane), surveys and reports from international organization or national institutions. We searched for the effect of C-section on child growth (body weight, length, nutritional status), and development (cognitive, memory, learning ability, intelligence quotient). We aim for studies with best methodology, i.e. systematic review and meta-analysis.

\section{Results and Discussion}

\section{C-section and child growth}

It has been hypothesized that Caesarean birth mode is associated with the changes in gut flora of infants. The pattern of gut microbiota in early life affects the composition of microbiota in the long run. ${ }^{8}$ Shao et al conducted a cross-sectional study testing 596 healthy babies and assessed the composition of gut microbiota between those vaginally delivered and Csection. The study found that birth mode is a significant factor in the difference of infant's gut flora. ${ }^{9}$ Gut microbiota samples from babies delivered vaginally were dominated with Bifidobacterium species; while these were found much less in Caesarean babies. Enterococcus species and other bacteria associated with hospital environment were found in substantially high amount in those born through $\mathrm{C}$-section. The differences are significant in the first three months of life, and slowly disappear after 6 months. ${ }^{10}$ Nonetheless, the early microbial colonization could have long-life implications in which it increases the risk of developing allergic diseases and disrupts the development pathway. ${ }^{11,12}$ The birth mode is not the only factor, breastfeeding, the introduction of solid food, and the use of antibiotics are other confounders affecting the infant's gut colonization in the first year of life. ${ }^{13,14}$
Gut microbiota have an important role in maintaining human health. The alteration of microbial gut colonization in the early life could lead to various immunologic diseases, neurodevelopmental disorders, and also obesity. An animal study revealed that microbiota increase nutrient uptake, including degradation of indigestible diet, and promotes fat storage, a possible mechanism leading to energy storage and obesity. ${ }^{15}$ The pattern of early microbial gut colonization could affect the risk of overweight and obesity in later childhood. A healthy human gut colonization is characterized by high amount of Bacteroides species and higher bacterial diversity. ${ }^{16}$ While an obese human gut microbiome has more Clostridium and Lactobacillus species. ${ }^{17}$ Caesarean babies have an altered gut microbiome with domination of bacteria found in hospital environment (e.g. Enterobacter, Haemophilus, Staphylococcus species), and less of Bacteroides species, Lactobacillus, Bifidobacterium species (which commonly found in vaginally delivered babies). ${ }^{18}$ This altered microbiome is associated with the risk of overweight and obesity in Caesarean babies. Table 1 summarized some evidences (systematic review/meta-analysis) related to risk of overweight and obesity in childhood and later life.

Overall, the studies showed positive association between Caesarean birth mode and risk of overweight and obesity in childhood, adolescence, and adulthood. The pooled ORs showed in general increased odds of overweight and obesity among children above 2 years old. Nevertheless, we should be aware that risk of obesity is not merely induced by birth mode, but also influenced by genetic and environmental factors, e.g. diet pattern, lack of physical activities, and socio-economic condition.

\section{C-section and child's cognitive development}

The intestinal microbiome affects not only the immune system and nutritional status of human, but also the neurodevelopment. A growing body of evidences demonstrates the importance of gut-brainaxis, a bi-directional communication between gastrointestinal tract and central nervous system. The interaction is facilitated through immunological, neural, and endocrine pathway. Studies linked the development of neurological 
disorders due to alteration in gut microbiota. ${ }^{23}$ Several mechanisms in which microbiota plays role in neurological disorders have been proposed. The alteration of gut microbiota affects the level of cytokine and stimulate inflammatory response. Microbiota could also elicit signals to the vagal nerve directly, which link to the brain. In addition, gut microbiota can activate hormone response which provides communication pathway to the brain. ${ }^{24}$ These indicate the initial gut colonization holds important process in infant's brain development.

As explained in the previous section, the delivery mode contributes to the variation in infant's gut microbiota. Caesarean babies have less diversity of microbes and less exposed to maternal microbes. ${ }^{25}$ The birth mode, aside from other factors (e.g. gestational age, fetal distress, use of antibiotics in utero) accounts for the alteration of gut microbiota in Caesarean babies. Table 2 showed a summary of evidences linking C-section and child's cognitive development (memory, IQ, linguistic). Nonetheless, we could not find the highest level of evidence, i.e. systematic review/meta-analysis. Hence, we presented several observational studies in Table 2.

Studies compared between planned C-section or maternal request with vaginal delivery and assessed the outcome, i.e. cognitive ability, learning ability, intelligence quotient, in preschool or school-aged children. One study found significant negative association between $\mathrm{C}$-section and child's cognitive ability (numeracy, reading, grammar at age 8-9).
The study also found the significant relationship between breastfeeding, obesity, and autism spectrum disorder with cognitive outcomes. A review also mentioned that the role of breastfeeding even in the specific working mothers' population should be empowered as the benefits of exclusive breastfeeding to support growth and development of babies were well established. ${ }^{26}$ Hence, even though the study adjusted these confounding factors, there were still unexplained factors that could influence child's cognitive ability. Other studies did not able to show any clear relationship between $\mathrm{C}$-section and cognitive outcomes. Therefore, we cannot support the notion that Caesarean babies had delayed cognitive development compared with vaginal delivered babies.

\section{Conclusion}

Our review identified evidences that assessed the potential risks of $\mathrm{C}$-section on child growth and especially on cognitive development. Based on the current available evidences, positive association was found between Caesarean birth and risk of overweight/obesity in childhood, and continued to adolescence, and adulthood. While, in terms of cognitive ability, there has not been sufficient evidences to confirm the association between $\mathrm{C}$ section and child's cognitive outcomes.

Table 1. Risk of overweight/obesity in childhood and beyond

\begin{tabular}{|c|c|c|c|c|c|}
\hline Author & Year & $\begin{array}{l}\text { n included } \\
\text { studies }\end{array}$ & Risk in children & Risk in adolescents & Risk in adults \\
\hline Li HT et al ${ }^{19}$ & 2013 & 9 & $\begin{array}{l}\text { 3-8 years old: } \\
1.32(1.15-1.51)\end{array}$ & $\begin{array}{l}\text { 9-18 years old: } \\
1.24(1.00-1.54)\end{array}$ & $\begin{array}{l}>18 \text { years old: } \\
1.50(1.02-2.20)\end{array}$ \\
\hline Sutharsan $\mathrm{R}$ et $\mathrm{al}^{20}$ & 2015 & 14 & $\begin{array}{l}\leq 5 \text { years old: } \\
1.15(0.94-1.40)\end{array}$ & $\begin{array}{l}\text { 5-18 years old: } \\
1.09(0.91-1.30)\end{array}$ & $\begin{array}{l}>18 \text { years old: } \\
1.28(1.02-1.34)\end{array}$ \\
\hline Kuhle $\mathrm{S}$ et $\mathrm{al}^{21}$ & 2015 & 28 & $\begin{array}{l}\text { 2-18 years old: } \\
1.34(1.18-1.51)\end{array}$ & $\mathrm{N} / \mathrm{A}$ & $\mathrm{N} / \mathrm{A}$ \\
\hline Keag OE et $\mathrm{al}^{22}$ & 2018 & 6 & $\begin{array}{l}\text { Overweight at } 3- \\
13 \text { years old: } \\
1.22(1.06-1.41) \\
\text { Obesity at } 5 \text { years } \\
\text { old: } \\
1.59(1.33-1.90)\end{array}$ & $\begin{array}{l}\text { Obesity at } 6-15 \\
\text { years old: } \\
1.45(1.15-1.83)\end{array}$ & $\begin{array}{l}\text { Obesity at } 20-28 \\
\text { years old: } \\
1.34(1.25-1.44)\end{array}$ \\
\hline
\end{tabular}

Note: all studies assessed in the systematic review/meta-analysis were observational/longitudinal studies. 
Table 2. Summary of evidences linking C-Section and children's cognitive development (memory, IQ, linguistic)

\begin{tabular}{|c|c|c|c|c|c|c|c|}
\hline Author & $\begin{array}{l}\text { Publication } \\
\text { Year }\end{array}$ & $\begin{array}{l}\text { Study } \\
\text { Design } \\
\end{array}$ & $\begin{array}{l}\text { n of } \\
\text { participants }\end{array}$ & Location & Groups & Age group & Outcomes \\
\hline $\begin{array}{ll}\text { Hanrahan } & M \\
\text { et } \mathrm{al}^{27} & \end{array}$ & 2019 & Cohort & 8,845 & UK & $\begin{array}{l}\text { Normal } \\
\text { delivery vs } \\
\text { planned CS }\end{array}$ & $\begin{array}{l}3-11 \text { years old } \\
\text { for verbal } \\
\text { cognitive } \\
\text { ability } \\
5-11 \text { years old } \\
\text { for visual- } \\
\text { spatial } \\
\text { cognitive } \\
\text { ability }\end{array}$ & $\begin{array}{l}\text { Delay in verbal } \\
\text { cognitive } \\
\text { ability: } \\
0.65(0.45- \\
0.94) \\
\text { Delay in } \\
\text { visual-spatial } \\
\text { cognitive } \\
\text { ability: } \\
1.55(1.07- \\
2.25)\end{array}$ \\
\hline $\begin{array}{l}\text { Polidano } \mathrm{C} \text { et } \\
\mathrm{al}^{28}\end{array}$ & 2017 & Cohort & 3,666 & Australia & $\begin{array}{l}\text { Vaginal } \\
\text { delivery vs CS }\end{array}$ & 4 to 9 years old & $\begin{array}{l}\text { Difference in } \\
\text { numeracy } \\
\text { ability: } \\
-0.095(0.034)^{*}\end{array}$ \\
\hline Fox NS et $\mathrm{al}^{29}$ & 2017 & Cohort & 354 & US & $\begin{array}{l}\text { Planned vaginal } \\
\text { delivery vs } \\
\text { planned CS }\end{array}$ & 2 years old & $\begin{array}{l}\text { Learning } \\
\text { disability: } \\
-0.5 \% \\
(\mathrm{p}=0.902)\end{array}$ \\
\hline $\begin{array}{l}\text { Khadem } N \text { et } \\
\text { al30 }\end{array}$ & 2010 & $\begin{array}{l}\text { Cross- } \\
\text { sectional }\end{array}$ & 372 & Iran & $\begin{array}{l}\text { Vaginal } \\
\text { delivery vs CS }\end{array}$ & $6-7$ years old & $\begin{array}{l}\text { Intelligence } \\
\text { quotient: } \\
-0.61(p=0.46)\end{array}$ \\
\hline Li HT et $\mathrm{al}^{31}$ & 2011 & Cohort & 4,144 & China & $\begin{array}{l}\text { Spontaneous } \\
\text { vaginal delivery } \\
\text { vs CS on } \\
\text { maternal } \\
\text { request }\end{array}$ & $\begin{array}{l}\text { Preschool } \\
\text { children }\end{array}$ & $\begin{array}{l}\text { Full scale IQ: } \\
1.6(-1.3-4.5) \\
\text { Verbal IQ: } \\
2.3(-0.8-5.5) \\
\text { Performance } \\
\text { IQ: } \\
0.6(-2.0-3.3) \\
\end{array}$ \\
\hline
\end{tabular}

Note: *statistically significant $(\mathrm{p}<0.05)$

\section{Conflict of Interest}

Authors declared no conflict of interest regarding this article.

\section{Open Access}

This article is distributed under the terms of the Creative Commons Attribution 4.0 International Licence (http://creativecommons.org/licenses/by/4.0/), which permits unrestricted use, distribution, and reproduction in any medium, provided you give appropriate credit to the original author(s) and the source, provide a link to the Creative Commons license, and indicate if changes were made.

\section{Reference}

1. Lumbiganon $\mathrm{P}$, Laopaiboon M, Gülmezoglu AM, et al. World Health Organization Global Survey on Maternal and Perinatal Health Research Group. Method of delivery and pregnancy outcomes in Asia: the WHO global survey on maternal and perinatal health 2007-08. Lancet. 2010;375:490-9.

2. Bodner K, Wierrani $\mathrm{F}$, Grünberger $\mathrm{W}$, BodnerAdler B. Influence of the mode of delivery on maternal and neonatal outcomes: a comparison between elective cesarean section and planned vaginal delivery in a low-risk obstetric population. Arch Gynecol Obstet. 2011;283:11938.

3. Agency of Health Research and Development (Indonesia). Basic Health Research 2018 
4. World Health Organization. WHO Statement on Caesarean Section Rates. Geneva; 2015

5. Ye J, Betrán AP, Guerrero-Vela M, Souza JP, Zhang J. Searching for the Optimal Rate of Medically Necessary Cesarean Delivery. Birth 2014; 41: 23744.

6. Potter JE, Berquo' E, Perpe' tuo IH, Leal OF, Hopkins K, Souza MR, Formiga MC. Unwanted caesarean sections among public and private patients in Brazil: prospective study. $B M J$ 2001;323:1155-8

7. Chen H, Tan D. Cesarean Section or Natural Childbirth? Cesarean Birth May Damage Your Health. Front Psychol. 2019;10:351.

8. Koenig, J. E. et al. Succession of microbial consortia in the developing infant gut microbiome. Proc Natl Acad Sci USA 2011;108:4578-85.

9. Shao Y, Forster SC, Tsaliki E, Vervier K, Strang A, Simpson N, et al. Stunted gut microbiota and increased pathogen colonisation associated with caesarean birth. Nature 2019;574:117-21. doi: 10.1038/s41586-019-1560-1

10. Rutayisire E, Huang K, Liu Y, Tao F. The mode of delivery affects the diversity and colonization pattern of the gut microbiota during the first year of infants' life: a systematic review. $B M C$ Gastroenterol. 2016;16:86.

11. Gaufin T, Tobin NH, Aldrovandi GM. The importance of the microbiome in pediatrics and pediatric infectious diseases. Curr Opin Pediatr. 2018;30:117-24.

12. Robertson RC, Manges AR, Finlay BB, Prendergast AJ. The human microbiome and child growth - first 1000 days and beyond. Trends in Microbiology 2019;27:131-47.

13. Azad MB, Konya T, Persaud RR, Guttman DS, Chari RS, Field CJ, et al. Impact of maternal intrapartum antibiotics, method of birth and breastfeeding on gut microbiota during the first year of life: a prospective cohort study. BJOG. 2016; 123:983-93.

14. Francino MP. Early Development of the Gut Microbiota and Immune Health. Pathogens 2014;3:769-90.

15. Bäckhed F, Ding H, Wang T, Hooper LV, Koh GY, Nagy A, et al. The gut microbiota as an environmental factor that regulates fat storage. Proc Natl Acad Sci USA 2004;101:15718-23.

16. Verdam FJ, Fuentes S, de Jonge C, Zoetendal EG, Erbil R, Greve JW, et al. Human intestinal microbiota composition is associated with local and systemic inflammation in obesity. Obesity 2013;21.

17. Villanueva-Millán. M, Pérez-Matute P, Oteo J. Gut microbiota: a key player in health and disease. A review focused on obesity. $J$ Physiol Biochem 2015;71:509-25.

18. F. Bäckhed, J. Roswall, Y. Peng, Q. Feng, H.Jia, P. Kovatcheva-Datchary, et al. Dynamics and stabilization of the human gut microbiome during the first year of life. Cell Host Microbe 2015; 17:690-703.

19. Li HT, Zhou YB, Liu JM. The impact of cesarean section on offspring overweight and obesity: a systematic review and meta-analysis. Int $J$ Obes (Lond). 2013;37:893-9.

20. Sutharsan R, Mannan M, Doi SA, Mamun AA. Caesarean delivery and the risk of offspring overweight and obesity over the life course: a systematic review and bias-adjusted metaanalysis. Clin Obes. 2015;5:293-301.

21. Kuhle S, Tong OS, Woolcott CG. Association between caesarean section and childhood obesity: a systematic review and meta-analysis. Obes Rev. 2015;16:295-303.

22. Keag OE, Norman JE, Stock SJ. Long-term risks and benefits associated with cesarean delivery for mother, baby, and subsequent pregnancies: Systematic review and meta-analysis. PLoS Med. 2018;15:e1002494.

doi:10.1371/journal.pmed.1002494

23. Borre YE, O'Keeffe GW, Clarke G, Stanton C, Dinan TG, Cryan JF. Microbiota and neurodevelopmental windows: implications for brain disorders. Trends Mol Med. 2014;20:509-18.

24. Wren AM, Bloom SR. Gut hormones and appetite control. Gastroenterology 2007;132:2116-30

25. Yang I, Corwin EJ, Brennan PA, Jordan S, Murphy JR, Dunlop A. The Infant Microbiome: Implications for Infant Health and Neurocognitive Development. Nurs Res. 2016;65:76-88.

26. Basrowi RW, Sastroasmoro S, Sulistomo AW, Bardosono S, Hendarto A, Soemarko DS, Sungkar A, Khoe LC, Vandenplas Y. Challenges and Supports of Breastfeeding at Workplace in Indonesia. Pediatr Gastroenterol Hepatol Nutr 2018 Oct;21(4):248-56.

27. Hanrahan M, McCarthy FP, O'Keeffe GW, Khashan AS. The association between caesarean section and cognitive ability in childhood. Soc Psychiatry Psychiatr Epidemiol. 2019;10.1007/s00127-01901798-4.

28. Polidano C, Zhu A, Bornstein JC. The relation between cesarean birth and child cognitive development. Sci Rep. 2017;7:11483.

29. Fox NS, Cohen N, Odom E, Gupta S, Lam-Rachlin J, Saltzman DH, Rebarber A. Long-term outcomes of twins based on the intended mode of 
delivery. The Journal of Maternal-Fetal \& Neonatal Medicine 2018;31:2164-9

30. Khadem N, Khadivzadeh $\mathrm{T}$. The intelligence quotient of school aged children delivered by cesarean section and vaginal delivery. Iran J Nurs Midwifery Res. 2010;15:135-40.
31. Li HT, Ye RW, Pei LJ, Ren AG, Zheng XY, Liu JM. Cesarean delivery on maternal request and childhood intelligence : a cohort study. Chin Med $J$ (Engl). 2011;124:3982-7 